\title{
BRITISH LIBRARY ADDITIONAL 14,686: INTRODUCTION, LIST OF READINGS, AND TRANSLATIONS OF COLOPHON AND NOTES
}

\author{
Nils Hallvard Korsvoll \\ MF NORWEGIAN SCHOOL OF THEOLOGY \\ LIV INGEBORG LIED \\ MF NORWEGIAN SCHOOL OF THEOLOGY \\ AND \\ JEROME ALAN LUND \\ ACCORDANCE BIBLE SOFTWARE
}

\begin{abstract}
The $1^{\text {th }}$ century Syriac lectionary manuscript British Library Additional 14,686 contains lections from the Old Testament, Catholic Epistles and Acts for Sundays and feast days of the church year. The present article provides a brief presentation of this manuscript, a full list of its prescribed lections, as well as transcriptions and translations of and annotations to the colophon and notes found on the last folios.
\end{abstract}


The manuscript British Library Additional (BL Add) 14,686 is a West Syriac lectionary for Sundays and dominical feasts of the church year, containing lections from the Old Testament, Catholic Epistles and Acts. ${ }^{1}$ The colophon of the manuscript (folio 205b), translated below, suggests that it was copied in the Deir al-Surian (the Monastery of the Syrians) in the Wadi al-Natrun in Egypt in $1255 .^{2}$

BL Add 14,686 is a relatively well preserved paper codex. It measures $18 \times 26 \mathrm{~cm}$, which is the common "utilitarian size" of Syriac codices. ${ }^{3}$ The codex consists of 208 leaves organised in 21 quires. Two leaves are wanting, one after folio 48 and another after folio 160 . The medieval binding of the codex has not survived. ${ }^{4}$

1 Our work on BL Add 14,686 is based, firstly, on Liv Ingeborg Lied's inspection of the manuscript in the British Library, 3-8 March 2013 and 20-21 February 2014 and, secondly, on digital images of the manuscript provided by the British Library. The list of readings in BL Add 14,686 was originally produced by Nils Hallvard Korsvoll and Lied for the online database ThALES (www.lectionary.eu). The present publication adds a more comprehensive introduction, as well as Jerome Lund's translation of and commentary to the colophon and notes. Thanks are due to Sebastian P. Brock for sharing with us a draft of the catalogue entry to Deir al-Surian Syriac Ms 33 before its publication in 2014.

2 With some exceptions, the list of lections provided by BL Add 14,686 overlaps with the list of lections of the lectionary manuscript Deir al-Surian Syriac Ms 33 (DS 33). Interestingly, in some of the places where the two manuscripts diverge there are marginal notes in DS 33 that point these out as mistakes, with reference to the sequence found here in BL Add 14,686. DS 33 is still kept in the Monastery of the Syrians and was described in Sebastian P. Brock and Lucas Van Rompay's Catalogue of the Syriac Manuscripts and Fragments in the Library of Deir al-Surian, Wadi alNatrun (Egypt) (OLA 227; Leuven: Peeters, 2014).

${ }^{3}$ Cf. Marlia M. Mango, "The Production of Syriac Manuscripts, 400700 AD," in Scritture, libri e testi nelle aree provinciali di Bisanto: Atti del seminaro del Erice (ed. Guglielmo Cavallo, Giuseppe de Gregorio and Marilena Maniaci; Spoleto: Centro Italiano di Studi Sull'Alto Medioevo, 1991), 161 79.

${ }^{4}$ The codex was rebound in a modern binding by Her Majesty's Stationary Office (HMSO) for the British Museum probably in the 1940s. Unfortunately, the HMSO did not keep any records or photographs of the older/original binding of the codex and it remains unknown (Emailcommunication with Martyn Jones,13 June 2013). 
The script is a regular Estrangelo. Occasional Greek system vowel signs have been added by a later hand. The text is written in two columns, each consisting of 17 or 18 lines. The titles of events and lections are inscribed in red ink. The quire marks are decorated with diamond shaped constellations of dots and dashes. The manuscript contains some notes from later readers and correctors. A short devotional note in Arabic appears on folio 208b, and a note in Serto is found on folio $208 \mathrm{a} .{ }^{5}$

The lectionary covers sixty-one Sundays and feast days, ${ }^{6}$ starting with the Consecration of the Church (folio 1b) and ending with the Festival of the Cross (205a). ${ }^{7}$ The number of lections at each event varies between two and nine. Three lections are most commonly prescribed for ordinary Sundays, but for important occasions such as Nativity, Epiphany, Palm Sunday and Easter Sunday the lectionary gives seven to nine lections. The last lection at each event is a lection from Acts or Epistles. The preceding lections are lections from various parts of the Old Testament, their literary contents fitting to the occasion. The text of each lection is given in full.

Two special traits deserve some additional attention. First, BL Add 14,686 is one of a pair. As suggested by the colophon, the lectionary manuscript has "a companion." The companion lectionary manuscript is in all due likelihood BL Add 14,687. ${ }^{\circ} \mathrm{BL}$ Add 14,687 provides another set of lections from the Old

${ }^{5}$ Cf., William Wright, Catalogue of Syriac Manuscripts in the British Museum Acquired since the Year 1838 (Vol. 1; London: The British Museum, 1870), 169-72. The present codicological description is based partly on William Wright's catalogue and partly on Lied's inspection of the codex in the British Library.

${ }^{6}$ Note, however, that according to the rubrics, the lections for the Sundays of the Easter Season were supposedly also to be read during the Week of White (in Albis). This means that the lectionary potentially contains lessons for altogether sixty-eight events.

${ }^{7}$ In addition, the lections for The Consecration of the Waters are added on folios 206a-207b. A note in the margin of folio 33 a notes that these lections are inscribed at the end of the codex. It is likely that they were supposed to be copied were the note occurs. Cf. BL Add 14,486 and 18,714 .

${ }^{8} \mathrm{BL}$ Add 14,687 is copied by the same scribe in the following year, the year 1256, also in the Monastery of the Syrians. Furthermore, the colophon describes this manuscript as "the second part" (folio 198r). 
Testament, Epistles and Acts for the same Sundays and feasts of the church year. ${ }^{9}$

Second, BL Add 14,686 contains lections from 4 Ezra and 2 Baruch. 4 Ezra 12:31-38 is scripted to be read on The Revelation of Joseph (folio 16a-b), 4 Ezra 7:26-42 is one of the lections for The Sunday of the Dead (folio 75b-77a), and 6:18-28 is copied on folios 195a-196a, to be read on The Festival of Mount Tabor. The lection from 2 Baruch (2 Bar. 44:9-15) appears after the lection from 4 Ezra on The Sunday of the Dead (folio 77a-b).

Lections from 4 Ezra and 2 Baruch are not commonly found in Syriac lectionary manuscripts. However, lections from these two writings do appear in the companion manuscript BL Add 14,687, in DS 33, a $13^{\text {th }}$ century manuscript still kept in the Deir al-Surian, as well as in the $15^{\text {th }}$ century Ms 77 of the Abraham Konath Collection. ${ }^{10}$ These lectionary manuscripts contain, mostly, the same selection of lections from 4 Ezra and 2 Baruch, scripting them to be read at the same events during the church year.

\section{LIST OF LECTIONS}

1. The Consecration of the Church (1b-4a)

Jer 31:10-26 (1b-2a)

Ezek 9:11-10:22 (2a-3a)

Acts 7:44-53 (3a-4a)

2. The Annunciation of Zechariah (4a-8a)

Gen 17:15-22 (4a-5a)

1 Sam 1:9-17 (5a-b)

2 Pet 1:1-15 (5b-7a)

${ }^{9}$ Cf., further, Odilo Heiming's description of Add 14,485, 14,486 and 14,487 in "Ein jakobitishces Doppellektionar des Jahres 824 aus Harran," in Kyriakon: Festschrift Johannes Quasten (Vol. 2, ed. Patrick Granfield and Josef A. Jungmann, Münster: Verlag Aschendorff, 1970), 768-99.

10 A lection from 4 Ezra is also found in the highly fragmentary manuscript BL Add 14,736. For further details, cf., Liv Ingeborg Lied, "4 Ezra in Syriac Lectionary Manuscripts - Three Points for Further Reflection," in Religion - Manuscripts - Media Culture (4 September 2015), http:/ /livlied.blogspot.no/2015/09/4-ezra-in-syriac-lectionarymanuscripts.html (Accessed 12 July 2016). 
3. Lections for The Annunciation of the Holy Virgin (7a-11a)

Judg 13:2-14 (7a-8b)

Zech 2:14-17+ 4:1-7+8:3-4 (8b-9b) $)^{11}$

1 Jn 3:2-17 (9b-11a)

4. The Visit [of Mary to Elizabeth] (11a-13a)

Gen 27:22-40 (11a-12b)

1 Pet 2:6-10 (12b-13a)

5. The Nativity of John the Baptist (13a-16a)

Gen 21:9-21 (13a-14a)

Ex 2:1-10 (14a-15a)

1 Jn 4:1-10 (15a-16a)

6. The Revelation of Joseph (16a-17b)

4 Ezra 12:31-38 (16a-b)

1 Pet 2:1-10 (16b-17b)

7. Lections for The Festival of the Nativity (17b-22b)

Gen 21:1-8 (17b-18a)

Josh 24:21-26 (18a-b)

1 Sam 1:19-23 (18b-19a)

Wis 8:19-9:3 (19a-b)

Jer 23:5-8 (19b)

Ezek 37:16-28 (19b-21a)

1 Jn 1:1-2:6 (21a-22b)

8. The Commemoration of the Holy Virgin (22b-26a)

Ex 3:1-10 (22b-23b)

Ezek 44:1-12 (23b-24b)

Acts 7:30-43 (24b-26a)

9. Lections for The Killing of the Infants (26a-30a)

Jer 31:15-26 (26a-27a)

Ezek 5:5-17 (27a-28b)

Acts 7:11-29 (28b-30a)

10. Lections for The Circumcision (30a-33a)

Gen 17:9-27 (30a-31a)

Deut 10:12-11:1 (31a-32a)

Acts 7:2-10 (32a-33a)

${ }^{11}$ The three excerpts from Zechariah are seamlessly bound together. 
11. Lections for The Epiphany (33a-40b)

Gen 24:1-28 (33a-35a)

Num 24:2-19 (35a-36a)

Josh 4:16-24 (36a-37a)

2 Sam 23:13-17 (37a-b)

2 Kings 2:19-25 (37b-38a)

Zech 6:9-15 (38a-b)

Dan 12:5-9 (38b-39a)

Acts 8:26-40 (39a-40b)

12. The Beheading of John the Baptist (40b-43b)

Jer 37:12-21 (40b-41b)

Isa 40:3-41:13 (41b-42b)

Acts 26:1-10 (42b-43b)

13. Lections on Mar Stephen the Protomartyr (43b-46a)

Sir 50:1-11+50:29-51:3 (43b-44b)

2 Chr 24:20-25 (44b-45a)

Acts 7:54-8:2 (45a-46a)

14. Lections for the Sunday after the Epiphany (46a[48b] $)^{12}$

Gen 25:19-34 (46a-47b)

2 Kings 3:13-25 (47b-48b)

Acts 2: 37-39 [47] (48b) ${ }^{13}$

15. The Second Sunday after the Epiphany $(49 a-51 b)$

Prov 8:22-9:9 (49a-50a)*

* One folio is missing. The rubric and first part of what is probably the first lesson is lost. The last half of the lesson is found on folio 49 a

Mic 5:1-8 (50a-b)

1 Pet 3:7-15 (50b-51b)

16. The Third Sunday after the Epiphany (51b-55b)

Joel 2:21-4:8 (51b-53b) Stephen.

${ }^{12}$ In DS Syr 33 the title is Lections for the Sunday after the Feast of

${ }^{13}$ One folio is missing at the end of the quire. The lesson from Acts breaks off in verse 39. DS Syr 33 has 7:37-47. 


$$
\begin{aligned}
& \text { Jer } 31: 2-12(53 b-54 b) \\
& 1 \text { Pet 2:1-10 (54b-55b) }
\end{aligned}
$$

17. The Fourth Sunday after the Epiphany (55b-58a)

1 Sam 16:1-13 (55b-56b)

Deut 18:9-16 (56b-57a)

1 Jn 4:11-21 (57a-58a) (variants)

18. Lections for The Presentation of Our Lord in the Temple (58a-61a)

Lev 12:1-8 (58a-59a)

2 Sam 5:1-6+5:17-21 (59a-60a)

Acts 24:10-23 (60a-61a)

19. Lections for the Week of Nineveh (61b-64a)

Num 5:5-10 (61b-62a)

Jonah 1:1-2:1 (62a-63b)

Acts 7:37-43 (63b-64a)

20. Lections for the Tuesday of the Week of Nineveh (64a-67b)

Mic 1:1-16 (64a-65b)

Nah 1:1-14 (65b-66b)

Acts 8:9-25 (66b-67b)

21. The Wednesday of the Week of Nineveh (68a-71b)

Zeph 1:11-2:4 (68a-69a)

Jonah 2:2-3:5 (69a-70a)

Jas 1:13-27 (70a-71b)

22. Lections for The Commemoration of the Priests (71b-74b)

Num 20:23-29 (71b-72a)

Job 14:7-22 (72a-b)

Wis 4:7-16 (72b-73b)

Acts 20:26-38 (73b-74b)

23. Lections for The Sunday of the Dead (74b-79b)

Ezek 37:1-14 (74b-75b)

4 Ezra 7:26-42 (75b-77a)

2 Bar. 44:9-15 (77a-b)

Jas 4:6-5:11(77b-79b)

24. Lections for the First Sunday of the Fast (79b-82b)

Gen 9:12-21 (79b-80a) 
1 Kings 18:29-46 (80a-81b)

Acts 11:19-26 (81b-82b)

25. Lections for the Monday in the First Week of the Fast (82b-85b)

Gen 1:1-13 (82b-83b) $)^{14}$

Wis $7: 7-24(83 b-85 a)$

Jas 1:2-12 (85a-b)

26. Tuesday in the First Week of the Fast (85b-88a)

Jer 11:1-8 (85b-86b)

Ezek 20:5-14 (86b-87b)

Jas 1:13-21 (87b-88a)

27. Lections for the Wednesday [in the First Week of the Fast] (88a-90b)

Gen 1:14-19 (88a-b)

Hag 2:17-23 (88b-89b)

Jas 1:22-2:5 (89b-90b)

28. Thursday in the First Week of the Fast (90b-93a)

Job 8:1-22 (90b-91b)

2 Kings 17:18-23 (91b-92a)

Jas 2:14-26 (92a-93a)

29. Friday in the First Week of the Fast (93a-95b)

Ezek 18:20-32 (93a-94a)

Zech 1:1-6 (94a-95a)

Jas 3:13-4:5 (95a-b)

30. Saturday in the First Week of the Fast (95b-100a)

Gen 2:8-25 (95b-97a)

Jer 17:19-25 (97a-98a)

Acts 12:1- 24 (98a-100a)

31. The Second Sunday of the Fast (100a-102b)

Gen 7:6-19 (100a-101a)

Jer 15:15-21 (101a-102a)

Acts 9:22-31 (102a-b)

32. The Third Sunday of the Fast (103a-108b)

${ }^{14}$ Although following the Peshițta in every other way, the manuscript here writes the first day in the description of both the second and the third days. 
Ezek 33:23-34:12 (103a-105a)

2 Chr 6:12-18 (105a-106a)

Deut 31:19-30 (106a-107a)

Acts 28:17-28 (107a-108b)

33. Lections for the Fourth Sunday of the Fast (108b111b)

1 Sam 7:10-17 (108b-109b)

Prov 16:12-32 (109b-110b)

Acts 20:22-32 (110b-111b)

34. The Fifth Sunday of the Holy Fast of the Forty

[Days] (111b-114b)

Jer 51:1-9 (111b-112b)

Sir 42:15-43:10 (112b-113b)

1 Pet 3:8-16 (113b-114b)

35. The Sixth Sunday, of the Miracles (114b-119a)

Deut 25:13-26:5 (114b-115b)

Judg 6:11-24 (115b-117a)

Ezek 13:1-16 (117a-118a)

1 Pet 4:12-19 (118b-119a)

36. Lections for Eucharist of the Forty [Days] on Friday (119a-121b)

Deut 1:3-14 (119a-120a)

2 Sam 24:18-25 (120a-b)

1 Pet 1:13-22 (120b-121b)

37. The Saturday of The Resurrection of Lazarus (121b124a)

2 Kings 20:1-10 (121b-122b)

Wis $11: 21-12: 4$ (122b-123b)

1 Pet 2:6-10 (123b-124a)

38. Lections for The Holy Sunday of the Hosannas

(124a-130a)

Gen 49:8-15 (124a-b)

Job 26:1-14 (124b-125a)

Judg 9:7-15 (125a-126a)

Prov 1:20-33 (126a-b)

$1 \mathrm{Kgs} 8: 1-6$ (126b-127b)

Zeph 3:14-20 (127b-128a) 


$$
\begin{aligned}
& \text { Jer 30:18-22 (128a-b) } \\
& \text { Dan 3:7-11 (128b-129a) } \\
& 1 \text { Jn 2:7-17 (129a-130a) }
\end{aligned}
$$

39. Lections for The Passion of our Saviour. Monday of the Passion (130a-133a)

$$
\begin{aligned}
& \text { Gen 22:1-14 (130a-131a) } \\
& \text { Judg 11:30-40 (131a-132b) } \\
& \text { Acts 25:6-12 (132b-133a) }
\end{aligned}
$$

40. Tuesday of the Week of the Passion (133a-135b)

$$
\begin{aligned}
& \text { Deut 31:16-20 (133a-b) } \\
& \text { Zech 12:1-8 (133b-134b) }
\end{aligned}
$$$$
1 \text { Jn 1:1-9 (134b-135b) }
$$

41. Lections for the Wednesday of the Week of the Trembling (135b-139a)

Lev 6:17-7:7 (135b-136b)

1 Sam 16:1-13 (136b-137b)

1 Kings 1:32-37 (137b-138a)

Acts 9:22-30 (138a-139a)

42. Lections for the Thursday of the Mystery (139a-143a)

Ex 12:1-11 (139a-140a)

Josh 5:9-12 (140a-b)

1 Sam 10:17-21 (140b)

2 Kings 23:21-25 (140b-141b)

Jer 18:18-23 (141b-142a)

Zech 11:10-14 (142a-b)

Acts 1:15-20 (142b-143a)

43. Lections for the Friday of the Crucifixion (143a-147b)

Zech 13:7-14:5 (143a-144a)

Hab 1:2-12 (144a-145a)

Lev 4:1-7 (145a-b)

2 Kgs 19:20-29 (145b-146b)

Acts 22:30-23:16 (146b-147b)

44. Lections for The Adoration of the Cross (147b-150a)

Ex 17:8-16 (147b-148b)

Josh 8:18-25 (148b-149a)

1 Pet 2:19-25 (149a-150a) 
45. Lections for the Saturday of the Good Tidings (150a153b)

$$
\begin{aligned}
& \text { Gen 8:1-12 (150a-151a) } \\
& \text { Jer 38:3-13 (151a-152a) } \\
& \text { Judg 7:9-15 (152a-153a) } \\
& \text { Acts 3:11-21 (153a-b) }
\end{aligned}
$$

46. Lections for the Great Sunday of the Resurrection (153b-160a)

$$
\begin{aligned}
& \text { Ex 40:17-23 (154a-b) } \\
& \text { Isa 60:1-7 (154b-155a) } \\
& \text { Judg 6:11-16 (155a-b) } \\
& \text { Joel 2:21-3:5 (155b-156b) } \\
& \text { Mic 7:11-20 (156b-157b) } \\
& \text { Dan 6:19-25 (157b-158a) } \\
& \text { Acts 2:22-43 (158a-160a) }
\end{aligned}
$$

47. Lections for the Second Sunday after the Resurrection, and Monday [of the Week] of White (160a-161b)

$$
\text { Gen 41:41-46* (160a-) }
$$

*One folio is lost. Comparing with DS Syr 33, it is likely that the folio contained the last five words of verse 46 in the lection from Gen 41:41-46; a lection from Judg 8:13-21; as well as verse 19 and the four first words of verse 19 in the lection from 1 Pet 2:19-25.

$$
1 \text { Pet 2: [19] * 20-25 (-161b) }
$$

48. The Third Sunday after the Resurrection, and Tuesday of the Week of White (161b-164a)

$$
\begin{aligned}
& \text { Ex 14:26-31 (161b-162a) } \\
& \text { Josh 6:10-17 (162a-163a) } \\
& \text { Acts 13:26-39 (163a-164a) }
\end{aligned}
$$

49. The Fourth Sunday after Resurrection, and Wednesday of the Week of White (164a-167a)

Ex 40:2-16 (164a-b)

Josh 2:1-6 (164b-165b)

Acts 4:8-21 (165b-167a) 
50. The Fifth Sunday after the Resurrection, and Thursday of the Week of White (167a-171a)

Ex 34:4-12 (167a-168a)

Mic 4:1-7 (168a-b)

Zech 8:4-9 (168b-169b)

1 Jn 4:19-5:15 (169b-171a)

51. Lections for the Friday of the Week of White, and the Sixth Sunday after the Resurrection (171a-173b)

Deut 16:1-8 (171a-b)

Josh 8:30-33 (171b-172b)

Prov 9:1-11 (172b-173a)

1 Pet 3:17-22 (173a-b)

52. The Seventh Sunday after the Resurrection, and the

Saturday of the Week of White (173b-175b)

Josh 1:5-9 (173b-174a)

1 Kings 17:17-22 (174a-b)

Acts 26:19-25 (174b-175b)

53. The Eight Sunday after the Resurrection, as also New Sunday (175b-179a)

Jer 1:4-12 (175b-176a)

2 Sam 7:18-26 (176a-177a)

Jer 26:1-6 (177a-178a)

Acts 6:8-7:1+7:54-60 (178a-179a $)^{15}$

54. Lections for The Ascension (179a-182b)

Deut 9:26-10:5 (179a-180a)

Jer 31:31-34 (180a-181a)

Ezek 10:18-22 (181a-b)

Acts 1:1-11 (181b-182b)

55. Lections for the Sunday of Pentecost (182b-187b)

Ex 19:1-11 (182b-183b)

Prov 4:18-5:2 (183b-184b)

2 Kgs 2:13-17 (184b-185a)

Dan 5:7-19 (185a-186b)

Acts 2:1-11 (186b-187b)

15 The two excerpts from Acts are seamlessly bound together in the middle of the second column on folio $178 \mathrm{~b}$ and appear as one lection. 
56. Lections for The [Commemoration of the] Apostles (187b-189b)

Jer 16:16-21 (187b-188a)

Dan 1:1-9 (188a-189a)

Acts 1:1-14 (189a-b)

57. Lections for The [Commemoration of the] Martyrs and the Holy Fathers (189b-194a)

Mal 3:13-24 (189b-190b)

2 Kings 2:1-12 (190b-192a)

Acts 12:1-17 (192a-194a)

58. Lections for The Festival of Mount Tabor (194a197a)

Deut 16:13-17:1 (194a-195a)

4 Ezra 6:18-28 (195a-196a)

2 Pet 3:8-15 (196a-197a)

59. Lections for The Decease of the Virgin Mary (197a201a)

$$
\begin{aligned}
& \text { Ex 19:16-20:6 (197a-198b) } \\
& \text { Josh 3:1-17 (198b-200a) } \\
& 1 \text { Jn 2:23-3:3 (200a-201a) }
\end{aligned}
$$

60. Lections for The Festival of the Saving Cross (201a205a)

$$
\begin{aligned}
& \text { Num 21:4-8 (201a-b) } \\
& 1 \text { Sam 17:37-54 (201b-203b) } \\
& \text { Dan 7:21-28 (203b-204a) } \\
& \text { Acts 13:26-38 (204a-205a) }
\end{aligned}
$$

"The end of the first part of the lections for the dominical feasts"

61. Lections for The Consecration of the Waters (206a207b)

Deut 15:22-25 (206a-b)

2 Kings 2:19-22 (206a)

Dan 12:5-9 (206b)

Acts 8:26-40 (206b-207b) 
COLOPHON (FOLIO 205B) ${ }^{16}$

Text

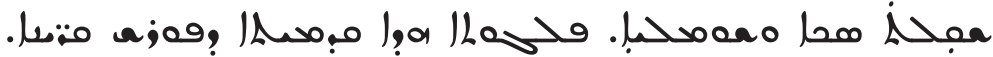

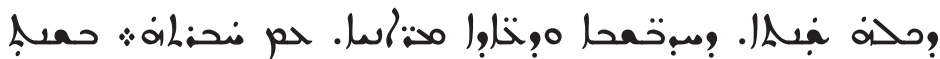

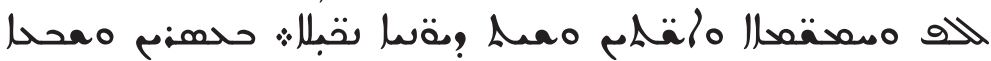

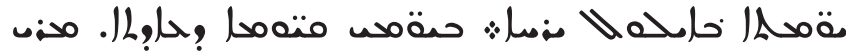

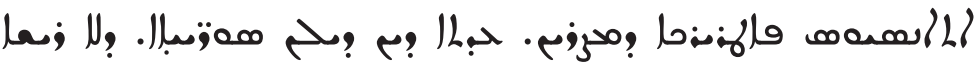
Loa

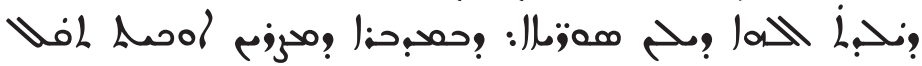

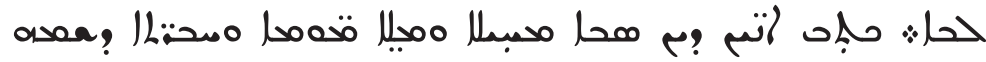

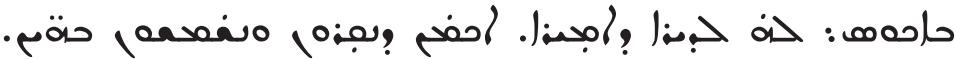

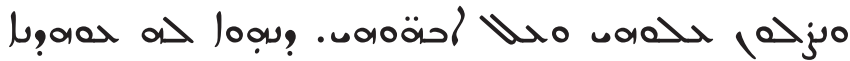

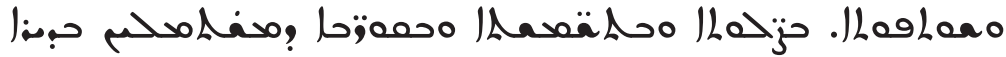

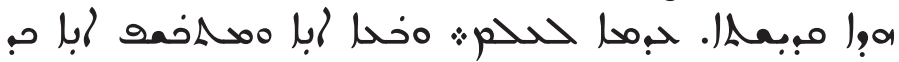
مهله

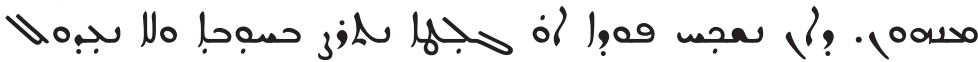

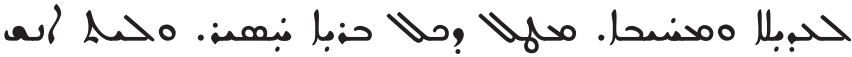

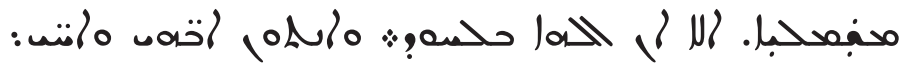

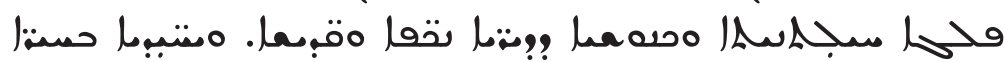

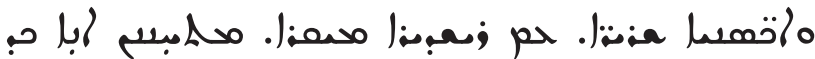

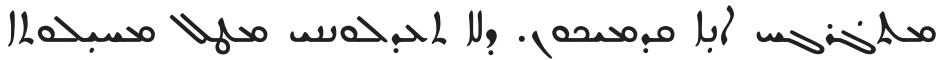

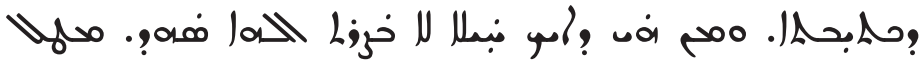

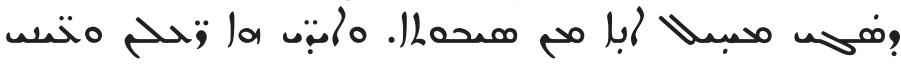

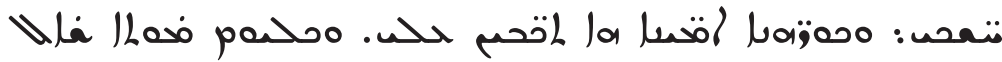

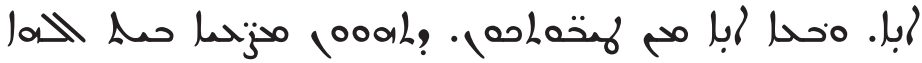

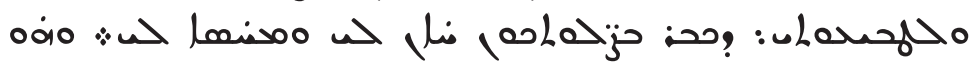

${ }^{16}$ Folio 205b contains three separate notes. The first (the colophon) and third notes are written with serto script, while the scribe wrote the second note, a doxology, with estrangelo script. 

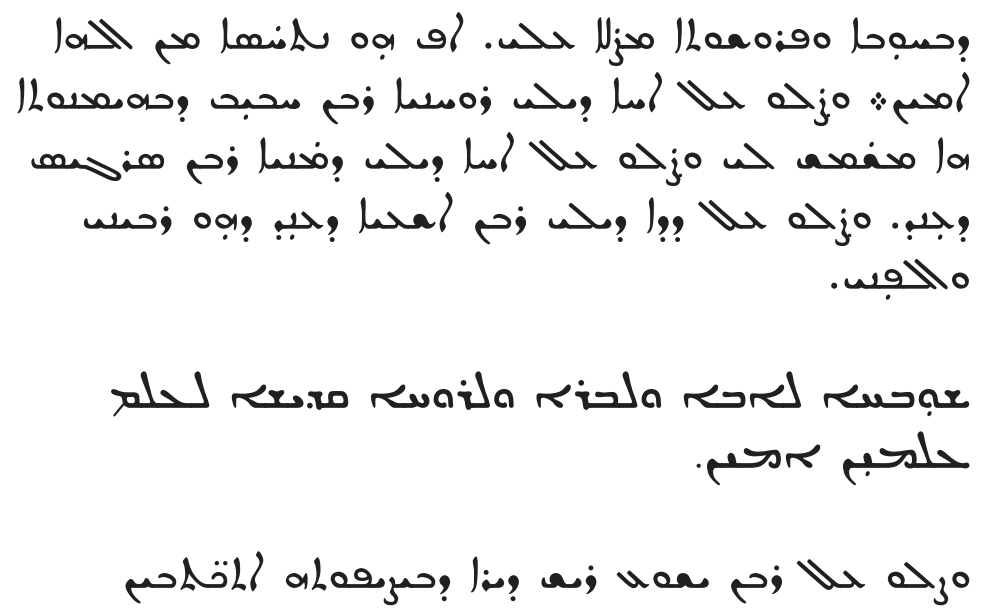

\section{Translation}

This first half of the lectionary ${ }^{17}$ of the entire year, of Sundays and dominical feasts, with its companion [volume], has reached full completion ${ }^{18}$ in the year $1566^{19}$ of the deceitful Greeks, on the $27^{\text {th }}$ day ${ }^{20}$ in the month Elul, in the days of the overseers of the church - Mar Athanasius was patriarch of Egypt. ${ }^{21}$ Moreover, ${ }^{22}$ the church of us Syrians was without a head at that time. ${ }^{23}$ Moreover, it ${ }^{24}$ and its companion were written at the holy monastery of 'The Bearer of God'25 of us Syrians, which is in the desert of Egypt, that

${ }^{17}$ Literally, "the division of readings."

${ }^{18}$ Literally, "end and completion."

${ }^{19}$ Since the Seleucid era began either 311 or 312 BC, 1566 of the Greeks is equivalent to AD 1254 or 1255.

${ }^{20}$ Literally, "in the 27 days."

21 Athanasius apparently refers to the Coptic patriarch Athanasius III, to be distinguished from the Greek patriarch by the same name who ruled later in the same century from the same city, Alexandria.

${ }^{22}$ In this text the particle dèyn functions as a marker to introduce an additional element into the narrative. Consequently, I have rendered it as 'moreover'.

23 That is, the Syrian Orthodox see of Antioch was vacant.

${ }^{24}$ The Syriac uses the feminine personal pronoun 'she' because the referent pälgùta' 'half is feminine.

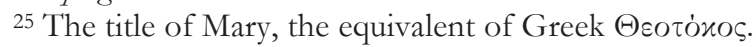


is, 'The Weigher of the Heart'. ${ }^{26}$ Moreover, an old man, feeble and full of defects and sores, whose name was Bacchus, wrote them for the aforementioned monastery so that they might read and serve with them, and they should pray for him and for his fathers, and that he might have a remembrance and participation in the prayers and in the services and in the liturgies that are performed at this holy monastery, forever.

Now I entreat and supplicate, while prostrating myself before every discerning brother who reads in them or recites ${ }^{27}$ from them, that if he finds an error or mistake he should correct (it) in love and should not reproach the one deserving of reproof, even the guilty, because every creature ${ }^{28}$ lacks and no man is perfect, but God alone [is perfect].

And you my fathers and my brothers, a mighty troop, and congregation of modest and holy monks, and chosen hermits, and true strangers, ${ }^{29}$ with the honored abbot, ${ }^{30} \mathrm{I}$ implore, prostrating myself before you, that you do not reproach me because of the weakness of the writing, and inasmuch as according to strength I was not diminished — God witnesses — because I am very weak due to old age and my hands, see! they tremble, and my eyes have grown dim, and constant illnesses, see! they vex me, and daily I request death. So I entreat from your kindnesses that you be mediators between God and my low state, who already through your prayers shows me mercy and absolves me. And he that in love and discernment prays for me, may he also be absolved by God. Amen.

And pray for my spiritual brother, Rabban Habbib, who indeed faithfully serves me. And pray for my blood brother, Rabban Sergius, who has departed. ${ }^{31}$ And pray for my uncle Rabban Isaiah who has departed, ${ }^{32}$ who raised me and taught me.

${ }^{26}$ The expression 'The Weigher of the Heart' is the equivalent of Coptic si-hèt, the name given to Wadi al-Natrun, also called the Nitrian Desert.

27 Or: "copies."

${ }^{28}$ Vocalize the form as a passive participle, namely as bary $\vec{a}$.

${ }^{29}$ On the use of 'stranger' to describe the believer, see Heb 11:13.

${ }^{30}$ Literally, "head of the monastery."

31 That is, died.

32 That is, died. 
Doxology

Praise to the Father, and to the Son, and to the Holy Spirit, forever and ever. Amen.

Request for Intercessory Prayer

Pray for Rabban Jesus, the abbot, ${ }^{33}$ in whose care they were written.

\section{NOTE FOUND ON FOLIO $208 \mathrm{~A}^{34}$}

Text

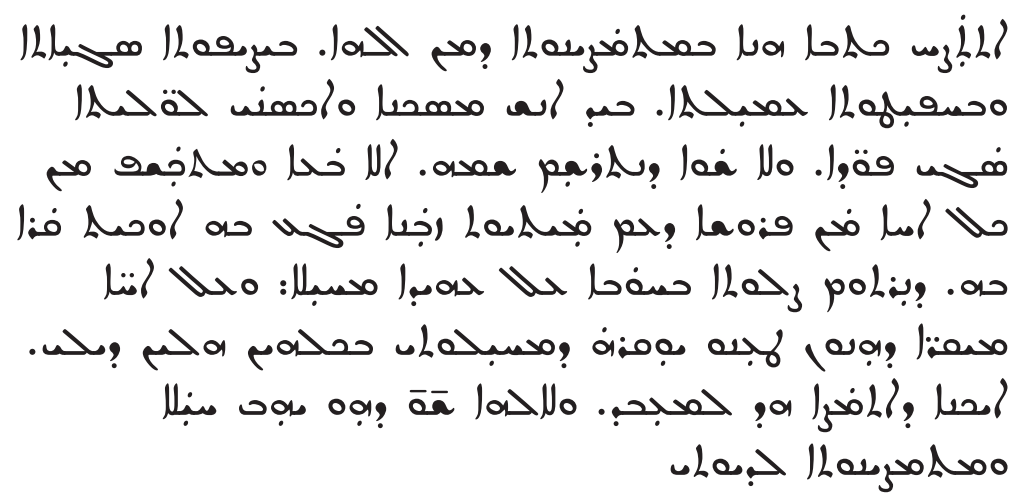

\section{Translation}

This writing was copied by the ability that is from God with much diligence and with laborious zeal by a poor man and a stranger with barbs, with many defects, so it is not fitting that his name be recorded. But he entreats and supplicates from every discerning brother who, as opportunity offers, encounters it, that is, reads in it, that he murmur a prayer in love for the aforementioned weak one, and for the honored brothers who have borne the weight of my weakness in all these matters of mine that I might be able to do this. And to God be the glory, he who has given strength and ability to my ink. ${ }^{35}$

${ }^{33}$ Literally, "head of the monastery."

34 This note is written with serto script.

35 It is possible to emend ldywty 'to my ink' to ldwywty 'to my wretched state' — see Add 14,687, folio 201b, note 2, that reads ldwyty. 


\section{BIBLIOGRAPHY}

Brock, Sebastian P. and Lucas Van Rompay. Catalogue of the Syriac Manuscripts and Fragments in the Library of Deir al-Surian, Wadi alNatrun (Egypt). Orientalia lovaniensia analecta 227. Leuven: Peeters, 2014.

Heiming, Odilo. "Ein jakobitishces Doppellektionar des Jahres 824 aus Harran." Pages 768-99 in Kyriakon: Festschrift Johannes Quasten. Vol. 2. Edited by Patrick Granfield and Josef A. Jungmann. Münster: Verlag Aschendorff, 1970.

Lied, Liv Ingeborg. "4 Ezra in Syriac Lectionary Manuscripts Three Points for Further Reflection." In Religion - Manuscripts Media Culture (4 September 2015), http://livlied.blogspot.no/ 2015/09/4-ezra-in-syriac-lectionary-manuscripts.html (Accessed 12 July 2016).

Mango, Marlia M. "The Production of Syriac Manuscripts, 400-700 ad." Pages 161-79 in Scritture, libri e testi nelle aree provinciali di Bisanto: Atti del seminaro del Erice. Edited by Guglielmo Cavallo, Giuseppe de Gregorio and Marilena Maniaci. Spoleto: Centro Italiano di Studi Sull'Alto Medioevo, 1991.

Wright, William. Catalogue of Syriac Manuscripts in the British Museum Acquired since the Year 1838. Vol. 1. London: The British Museum, 1870. Online: http://www.archive.org/stream/ catalogueofsyria01brituoft\#page/168/mode/2up. 